\title{
Pemberdayaan Nelayan Lokal Indonesia Untuk Mengatasi Penyelundupan di Batam
}

\author{
Kris Mada ${ }^{1}$ \\ “Tuhan menciptakan daratan dan lautan, lalu membagi daratan untuk manusia dan menjadikan lautan untuk semua. \\ Tidak pernah terdengar lautan terlarang untuk kaum tertentu" \\ Sultan Alaudin, Raja Gowa IX, 1615
}

\begin{abstract}
Abstrak
Mengontrol laut berjuta kilometer persegi membuat Indonesia memiliki batas maritim besar. Dibutuhkan sumber daya yang sangat besar untuk mengontrol perbatasan maritim secara optimal. Pengawasan untuk memastikan perbatasan tidak digunakan sebagai lintasan perdagangan gelap, perdagangan narkotika, dan penyelundupan senjata. Sayangnya, Indonesia belum memiliki kekuatan pokok minimum untuk mengontrol batas-batasnya. Sumber daya yang terbatas tercermin dalam Direktorat Jenderal Bea dan Cukai (DJBC) Kantor Batam, Kepulauan Riau. Agen avant garde dalam pencegahan penyelundupan tidak memiliki cukup tenaga dan kapal untuk rutin berpatroli di sekitar Batam, kota perbatasan yang terletak di Indonesia, dan perbatasan Malaysia-Singapura. Akibatnya, Batam menjadi salah satu pintu masuk dan keluar dari berbagai selundupan. Oleh karena itu, keterlibatan aktor-aktor non-negara untuk menjadi salah satu alternatif untuk mengatasi penyelundupan. Salah satu aktor negara di Batam adalah pelaut Indonesia lokal yang memiliki lebih banyak orang dan kapal dari DJBC.
\end{abstract}

Kata-kata kunci: penyelundupan, keamanan maritime, manajemen perbatasan, actor non Negara, pelaut local

\begin{abstract}
Control million of square kilometres ocean making Indonesia has enormous maritime boundaries. It takes enormous resources to control the maritime border optimally. Supervision, apropos, to ensure the border is not used as the trajectory of illicit trade, narcotic trafficking, and arms smuggling. Unfortunately, Indonesia hasn't had minimum essential force to control her boundaries yet. Limited resources was reflected in Directorate General of Custom and Excise (DGCE) Office Batam, Riau Islands. Avant garde agent in smuggling prevention does not have enough personnel and ships to routinely patrol around Batam, border city located in Indonesia, Malaysia and Singapore boundaries. Consequently, Batam become one of the entrances and exits of various contraband. . Therefore, the involvement of non-state actors to be one alternative to overcome smuggling. One state actors in Batam is a local Indonesian seafarer who has more people and boats than DJBC.
\end{abstract}

Keywords : smuggling, maritime security, boundaries management, non-state actors, local fisheries

\section{Pendahuluan}

Manajemen pengamanan perbatasan terus menjadi masalah yang kompleks. Tantangan-tangan baru bermunculan seiring perkembangan zaman. Para penjaga perbatasan harus berupaya menemukan cara baru untuk mengawasi lintas batas negara dan mengurangi, jika tidak dapat menghapuskan arus selundupan narkotika, illicit trade, dan selundupan senjata.

Manajemen perbatasan adalah konsep fleksibel dalam arti tingkat pengaturan pengamanan perbatasan akan tergantung pada kondisi dan hubungan politik, ekonomi, suku, dan agama di antara pelintas batas dan bentuk perbatasan itu sendiri (Janwal, 2002 :406426) .

Tentu, sangat jelas bahwa pengamanan perbatasan adalah tanggung jawab negara. Pemahaman ini amat mungkin dipengaruhi konsep jura regalia (Hak raja, antara lain untuk mengatur hal-hal terkait penegakan kedaulatan

\footnotetext{
${ }^{1}$ Alumni S1 Jurusan HI, FISIP, Universitas Muhammadiyah Yogyakarta. Saat ini bekerja sebagai wartawan Kompas di area Batam dan sekitarnya.
} 
serta jurisdiksi sipil) digunakan untuk membedakan mana perairan dan jalur pelayaran yang menjadi kekuasaan pemerintah dan yang bukan. Namun, peningkatan kekhawatiran atas ancaman maritim menyebabkan pemerintah tertentu melakukan alihdaya sebagian tugas pengamanan dan pengawasan perbatasan, termasuk perbatasan laut, pada aktor non pemerintah (Sciascia, 2013).

Pelibatan aktor non pemerintah dalam perlindungan perbatasan laut adalah salah satu alternatif yang dapat dipilih negara seperti Indonesia. Negara ini punya banyak keterbatasan untuk mengamankan perbatasan lautnya. Paling tidak, hal itu dibuktikan masih tingginya penyelundupan lewat perbatasan laut.

Tidak mudah mengandalkan lembaga pemerintah semata untuk pengawasan perbatasan laut dan menegah penyeludupan. Kekurangan peralatan, keterbatasan anggota serta anggaran menjadi alasan utama. Kombinasi alasan itu membuat patroli rutin di daerah perbatasan seperti di Batam, Kepulauan Riau tidak mudah dilakukan. Sementara di sisi lain, ada ribuan pelaut yang bisa dilibatkan dalam upaya pencegahan penyelundupan.

Paper ini mencoba mengurai cara pemanfaatan pelaut lokal di area Batam untuk mencegah penyelundupan. Di sini akan dielaborasi tantangan dan cara mengatasinya.

\section{Selayang Pandang Selat}

Indonesia sudah lama lama dikenal sebagai negara dengan seperangkat hukum yang bagus. Namun, sayangnya, aturan-aturan baik itu belum ditegakkan secara efektif.. Banyak alasan penyebab reputasi itu bertahan selama bertahun-tahun. Namun, alasan paling sederhana adalah : ketidakmampuan. Sarana maupun sumber daya manusia selalu menjadi masalah.

Belum tersedia cukup sumber daya untuk menerapakan serangkaian peraturan itu secara optimal pada wilayah luas. Tidak perlu sampai membahas pengawasan seluruh 3,5 juta kilometer persegi laut (Ministry of Marine Affairs and Fiseheries, 2011), dan 13.667 pulau (Ikawati, 2008) Indonesia . Pengawasan beberapa titik saja masih belum mencapai titik optimal. Ketidakmampuan dan ketidakoptimalan itu menjadi salah satu pemicu bisnis gelap terus bertahan. Dari Timur sampai barat, utara hingga selatan, pebisnis gelap terus menjalankan usahanya.

Daerah-daerah perbatasan paling sering menjadi lokasi bisnis gelap dan abu-abu berjalan. Batam di Kepulauan Riau, kota perbatasan Indonesia dengan MalaysiaSingapura tak luput dari jangkauan bisnis gelap dan abu-abu. Bentuk dan cara kerjanya beragam. Salah satunya adalah penyelundupan. Sebagian pelaku menyadari mereka menyelundup. Sebagian lagi merasa hanya menjalankan tradisi turun temurun. Mereka yakin yang dilakukan sekedar berdagang dengan kerabat di tanah seberang..

Penduduk Kepulauan Riau memang 
tetap merasa warga Singapura dan Malaysia, khususnya di Negara Bagian Johor, sebagai kerabat mereka. Konsep persaudaraan itu sudah jauh lebih dahulu ada sebelum konsep negara bangsa modern dikenal di kawasan itu. Mereka pertama-tama merasa sebagai anggota puak melayu, baru merasa menjadi Indonesia, Malaysia, atau Singapura. Konsep negara bangsa yang diperkenalkan orang Eropa adalah hal asing bagi mereka(Tagliacozzo, 2001).

Sebagai melayu pesisir, mereka hanya mengenal Selat Malaka sebagai penghubung pulau-pulau di ujung Semenanjung Malaya. Sementara orang Eropa dan negara bangsa di kemudian hari membagi Selat itu menjadi tiga : Malaka, Singapura, Phillips.

Dua perbedaan konsep, soal identitas dan pengenalan wilayah, tentu punya konsekuensi. Di antaranya : Sejak dulu mereka mereka yakin hanya berdagang antarpulau. Sementara bagi aparat Indonesia, Malaysia, Singapura, mereka menyelundup atau berdagang secara ilegal.

\section{Jaringan Dari Masa Lalu}

Sebenarnya, tak hanya aparat Indonesia, Singapura, Malaysia saja yang menyebut sebagian perdagangan di Selat Malaka, khususnya di perairan antara BatamJohor-Singapura, sebagai perdagangan ilegal. Sejak kekaisaran Sriwijaya menguasai wilayah itu, istilah perdagangan ilegal sudah dikenal.

Sriwijaya mengerahkan banyak sumber daya untuk memastikan seluruh pelayaran di
Selat Malaka tetap dalam kontrol mereka (Frecon, 2008). Imperium itu mempekerjakan penduduk setempat untuk mencegah pedagang ilegal, biasanya kapal-kapal China dan India, melayari selat tanpa membayar pajak atau membeli dari jalur resmi yang direstui negara. Namun, tetap saja muncul beragam upaya

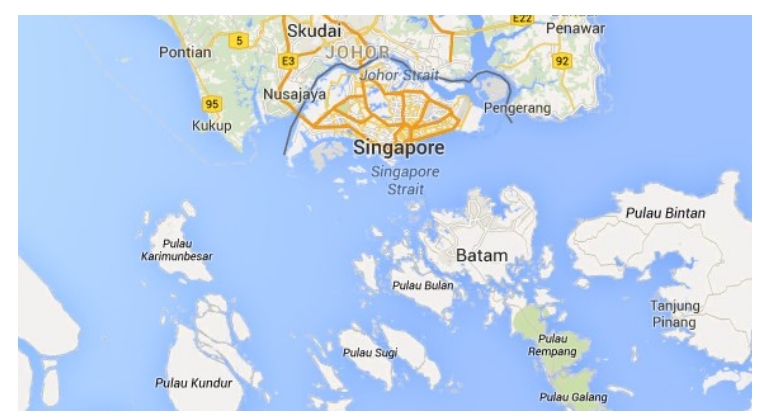

menyiasati jalur perdagangan resmi (Erman, 2009).

Jauh setelah Sriwijaya runtuh, perdagangan ilegal di Selat tetap berlangsung. Aktor, komoditas, modus terus berganti sesuai perkembangan zaman. Tidak kurang dari Pemerintah Indonesia, pada hari-hari pertama negara itu berdiri, juga pernah menjadi aktor penyelundup di perairan itu (Ramcharan, 2006).

Wakil Presiden pertama Indonesia, Muhammad Hatta memberikan otoritas kepada sekelompok orang untuk menyelundupkan 22 opium mentah pada hari-hari pertama Indonesia merdeka. Hasil penyelundupan itu antara lain dipakai untuk mendanai misi diplomatik dan membeli senjata.

Banyak orang terlibat dalam berbagai penyelundupan yang dilakukan berkali-kali atas restu Presiden Indonesia, Soekarno dan Wakilnya, M Hatta itu. Sejumlah pelaku 
penyelundupan itu, John Lie (Santosa, 2014) dan Tony Wen (Sofyan, 2011) kemudian dikenang sebagai pahlawan. Bahkan, salah satu korvet terbaru Indonesia dinamai John Lie (Santosa, 2014).

Seperti kapal-kapal perang lain yang dioperasikan TNI AL, KRI John Lie-358 punya tugas beragam. Salah satunya : mencegah penyelundupan. Memang, belum jelas kapan KRI John Lie-358 yang bergabung dengan TNI AL pada semester II 2014 itu akan berpatroli di sekitar Batam. TNI AL masih mengandalkan kapal-kapal lain di bawah koordinasi Gugus Keamanan Laut dan Gugus Tempur Laut Komando Armada RI Kawasan Barat untuk mengamankan perairan di sekitar Selat Malaka, termasuk pesisir Batam..

Selain TNI AL, instansi lain yang bertanggung jawab mengontrol perbatasan Indonesia-Malaysia-Singapura, termasuk di pesisir Batam, adalah Direktorat Jenderal Bea dan Cukai (DJBC). Dengan 62 petugas bidang Penyidikan dan Penindakan serta sembilan kapal, Kantor Bea dan Cukai Batam diharuskan mencegah perdagangan ilegal dan penyelundupan di pesisir Batam.

\section{$\underline{\text { Peta Batam }}$}

\section{Dari sumber internet}

\section{Sandungan Di Laut}

Seperti terlihat di peta, Kota Batam tepat berada di tepi Selat Malaka serta berdekatan dengan Johor, Malaysia dan Singapura. Berada di tepi Selat Malaka membawa berkah sekaligus petaka. Berkah karena Batam bisa menjadi daerah industri dengan ongkos angkut murah dan langsung ke urat nadi pelayaran dunia.

Petaka karena, seperti dinyatakan Kapolri pertama, Hoegeng, Selat Malaka mempertahankan fungsi lamanya sebagai tempat transit gelap untuk aneka komoditas dari Sumatera ke Malaysia. Perahu dan kapal yang dimuati aneka selundupan mulai pelayaran di tengah malam (Tagliacozzo,2002).

Barang-barang hasil selundupan itu antara lain didaratkan di Batam. Satu dari dua kota di Provinsi Kepulauan Riau itu punya lima pulau besar utama. Kecuali Pulau Bulan di pesisir barat, empat pulau lain terhubung jaringan jalan sepanjang hampir 100 kilometer dari Pulau Batam sampai ke Pulau Galang Baru.

Infrastruktur itu bagus untuk mobilitas orang dan barang. Namun, di sisi lain, kemudahan mobilitas di wilayah perbatasan (seperti Batam) menjadi tantangan besar untuk upaya pencegahan penyelundupan (Bhattacharyay, 2010). Penyelundup bisa mendarat di mana saja di pesisir empat pulau yang terhubung dengan jaringan jalan itu. 
Polisi dan DJBC menengarai sedikitnya 100 pelabuhan ilegal yang kerap digunakan untuk pendaratan kapal pembawa aneka barang dari dan ke Batam. Barang yang dibawa amat beragam (Tagliacozzo, 2002). Mulai dari kebutuhan sehari-hari, hingga produk terkait hewan liar (Mada, 2014). Sarana pengangkutnya juga beragam, dari perahu cepat hingga ke kapal-kapal ukuran 80 gross ton (Mada, 2014).

Untuk menangkap aktifitas itu, DJBC Batam sebagai garda terdepan hanya punya Sembilan kapal dan perahu patroli (Naim, 2014). Mereka juga hanya punya 62 orang di Bidang Penindakan dan Penyidikan. Dari 62 orang itu, hanya dua orang punya ijazah sebagai pelaut. (Pencawan, 2014). Sisanya adalah lulusan STAN atau pendidikan dasar calon pegawai DJBC yang tugas utamanya soal mengumpulkan pendapatan negara dari bea dan cukai (Anonim, 2014).

Sebagian dari mereka memang cukup beruntung mendapat pelatihan-pelatihan untuk menunjang tugas bidang Penyidikan dan Penindakan. Namun, lebih banyak yang mengandalkan berlajar sambil melakukan tugas di lapangan serta menimba ilmu dari praktik bersama senior. Para senior yang juga mendapatkan ilmu dengan cara belajar sambil bekerja di lapangan (Anonim, 2014).

Merekalah operator sembilan kapal yang ditempatkan di beberapa titik di Batam. Kapal-kapal itu ditempatkan, bukan berkeliling secara rutin di perairan Batam. Cara itu dilakukan karena dua hal : efisiensi anggaran dan kekurangan kapal.

Efisiensi berarti penggunaan bahan bakar secara baik. Setiap kapal berkecepatan 30 knot di DJBC Batam butuh 400 liter BBM untuk beroperasi selama satu jam dalam kecepatan maksimal. Kecepatan maksimal dibutuhkan dalam pengejaran sasaran seperti kapal-kapal penyelundup.

Untuk memutari dari Batam sampai Galang Baru butuh waktu minimal 90 menit dengan kapal paling cepat yang dimiliki DJBC Batam. Hal itu berarti, ada jeda lebih dari 80 menit pada setiap titik yang sudah dilewati kapal patroli.

Waktu sebanyak itu sudah lebih dari cukup bagi penyelundup untuk masuk atau keluar Batam. Para penyelundup rokok yang dikhususkan untuk dipasarkan di Batam paham betul soal itu. Dengan perahu-perahu berkecepatan 50 knot, mereka sudah berjarak sangat jauh dari Batam dalam 80 menit yang tidak terpantau DJBC itu (Anonim, 2014).

DJBC menyadari perlu tambahan personel dan kapal untuk mengawasi wilayah perbatasan seperti Batam. Namun, penambahan itu bukan perkara sederhana. Pengadaan setiap kapal baru membutuhkan paling sedikit tiga tahun sejak perencanaan sampai pengoperasian.

Tahun pertama untuk perencanaan dan pengusulan. Tahun kedua untuk penganggaran dan, bila cukup beruntung, untuk proses pengadaan. Tahun ketiga dan selanjutnya 
untuk pengerjaan. Bila dimungkinkan, maka penyiapan awak dapat dilakukan saat kapal dalam pengerjaan. Bila tidak, harus menunggu sampai ada anggaran lagi untuk merekrut tenaga baru.

Pengadaan kapal tidak bisa sekaligus banyak. Sebab, amat tergantung pada penganggaran pemerintah. Dengan APBN ratarata $\mathrm{Rp} 2.000$ triliun selama beberapa tahun terakhir, Indonesia harus sangat selektif mengatur belanja yang kebetulan semua dirasa prioritas serta harus segera dipenuhi.

Secara ringkas, ketidakcukupan anggaran, dilengkapi kontrol anggaran yang kurang menyebabkan tidak mudah untuk mendanai operasi pengamanan laut. Termasuk untuk pengadaan fasilitas dan sarana, perawatan, serta remunerasi pegawai (Dirhamsyah, 2005).

Indonesia memang berusaha secara rutin menggelar patroli terkoordinasi Malaysia untuk mengawasi perbatasan. Namun, kegiatan yang disebut Patkor Kastima itu lebih menyerupai seremonial dan wahana latihan kerjasama antara DCGE dan Kastam Malaysia. Sebab, patroli terkoordinasi hanya dilakukan beberapa hari dalam setahun. Saat kapal dari masing-masing negara berlayar berdampingan di dekat garis perbatasan. Di luar jadwal itu, patroli perbatasan dilakukan terpisah dan amat jarang bertemu di laut.

Ada pula kerjasama oleh instansi lain di kedua negara. Seperti dilakukan oleh TNI AL dan Tentara Laut Diraja Malaysia the
Malacca Straits Patrols (MSP). MSP terdiri dari tiga elemen yakni Eyes in the Sky (EIS) initiative dan Intelligence Exchange Group (IEG). IEG berkembang menjadi the Malacca Straits Patrols Information System (MSP-IS) Storey, 2015). Namun, tetap saja penyelundupan berlangsung dengan beragam modus, aktor, dan barang. Mereka mengintai setiap detik yang mungkin terlewat dari pengawasan petugas lalu bergegas menyelundup.

\section{Pelibatan Aktor Non Negara}

Dengan kondisi seperti itu, tentu saja dibutuhkan terobosan-terobosan. Salah satunya pemanfaatan non state aktor untuk mengamankan perbatasan dari aksi-aksi penyelundupan. Memang, pengamanan perbatasan adalah tanggung jawab negara dan lembaga-lembaganya. Namun, kondisi masa kini menunjukkan, peran aktor non negara dalam persoalan itu semakin meningkat (Ford et al, 2013).

Pelibatan aktor non negara dalam pengawasan perbatasan memang bukan hal baru. Sejumlah maskapai flagship dipercaya pemerintahnya untuk memberikan layanan imigrasi di pesawat (Imigrasi, 2014). Pelayanan yang disebut untuk mempermudah pelancong itu adalah bentuk pelibatan non state aktor dalam pengawasan perbatasan .

Dalam konteks penyegahan penyelundupan, pola serupa dapat pula diterapkan. Untuk kasus Batam, salah satu 
aktornya adalah para pelaut yang tersebar di pesisir Batam. Jumlah pelaut --yang di dalam kategori itu termasuk nelayan, juru mudi perahu, awak kapal-- mencapai ribuan ( Nurul, 2013). Tidak hanya banyak mereka juga tersebar di hampir seluruh pesisir Batam. Bahkan, juru mudi perahu adalah andalan orang-orang untuk bergerak antarpulau di Batam,.

Memang, pelibatan mereka akan sangat dibatasi hanya sebagai mata dan telinga pegawai DJBC Bidang Penyidikan dan Penindakan. Mereka dimanfaatkan untuk memberi infomasi awal soal kapan dan di mana penyelundup akan lewat. Tugas mereka hanya mengirimkan sms agen DJBC tentang informasi penyelundupan. Tidak dapat dipungkiri bahwa sebagian dari mereka terlibat dalam penyelundupan (Metro, 2013).

Mereka mengangkut sejumlah barang, biasanya untuk kebutuhan sehari-hari dari Malaysia dan Singapura yang lebih mudah dijangkau oleh penduduk pulau-pulau di Batam. Selain itu, ada sejarah sangat panjang soal perdagangan antarpulau di sekitar Semenanjung Malaya yang kini terbagi atas tiga negara. Sejarah itu antara lain terbentuk karena Batam, Singapura, dan Johor samasama pernah di bawah kekuasaan Kesultanan Johor (Tagliacozzo, 2012).

Fakta itu adalah tantangan pertama pelibatan pelaut dalam menegah penyelundupan. Untuk mencegah mereka yang terlibat dalam sindika dijadikan mitra penegahan penyelundupan, penting sekali pemeriksaan mendalam atas latar belakang. Di mana mereka tinggal, dengan siapa mereka bergaul, bagaimana mereka mendapat uang adalah sejumlah poin yang harus dipastikan sebelum mereka dipilih dan dilibatkan dalam penegahan penyelundupan.

Setelah lolos verifikasi awal, seorang DJBC harus menyiapkan salah seorang pegawainya untuk menjadi penghubung mereka. Tugas agen penghubung adalah memastikan informan tidak memberikan info palsu. Caranya antara lain dengan mengontak dengan informan lain. Informan yang dijaga tidak pernah saling tahu bahwa mereka memasok informasi untuk agen DJBC.

Memang, tidak mudah membuat pelaut bersedia memberikan informasi. Karena itu, agen DJBC kerap mengunjungi mereka sekedar untuk berbincang ringan atau memberi hadiah-hadiah kecil. Masih amat banyak pelaut di Batam sangat bangga bila memakai hadiah, yang bisa berupa topi, baju, atau paying pemberian DJBC.

Mereka juga merasa tergugah setelah diajak berdiskusi soal aliran narkotika dari Malaysia ke Indonesia (Mada, 2014). Mereka tidak ingin keluarganya menjadi konsumen narkotika (Anonim, 2014).

Memang, diskusi dan hadiah kecil tidak membuat mereka memberikan informasi untuk big fish. Karena itu, Bidang Penyidikan dan Penindakan DJBC menyiapkan anggaran yang disebut dana penggalangan informasi. Dana itu 
antara lain digunakan sebagai insentif bagi para informan. Sesekali berupa pulsa ponsel, kadang kala berupa uang dalam jumlah hingga jutaan rupiah. Uang diberikan terutama bila informasinya terkait penyelundupan narkotika atau barang bernilai miliaran.

Meski terdengar besar untuk ukuran insentif, tetap saja jumlahnya tidak sebanding dengan anggaran berpatroli rutin atau membeli kapal baru. Lebih efisien menggerakan kapal ke sasaran yang ditetapkan berdasarkan informasi intejelen dibandingkan berpatroli rutin mengelilingi Batam. Anggaran untuk penggalangan informasi itu diaudit secara rutin oleh BPKP dan BPK. Audit yang berusaha mencegah fraud pada anggaran.

\section{Tawaran Untuk Hari Depan}

Keterbatasan peralatan dan kekurangan sumber daya pada lembaga-lembaga penegak hukum di Indonesia tidaklah mudah diatasi. Terobosan-terobosan diperlukan untuk menegah penyelundupan di daerah perbatasan.

Pemanfaatan pelaut lokal Indonesia di sekitar Batam untuk menegah penyelundupan dapat dijadikan salah satu alternatif oleh DJBC. Serangkaian seleksi ketat sebelum memutuskan pelaut pantas jadi informan, mutlat dilakukan.

Mereka yang lolos seleksi tetap dipantau untuk menjaga kualitas informasi. Jangan sampai mereka memasukkan informasi palsu karena mendapatkan insentif lebih besar dari penyelundup atau karena ingin menjatuhkan pihak lain. Pengawasan ketat terhadap informan terpilih harus terus dilakukan untuk menjaga mereka tidak menyalahgunakan posisinya.

Pembinaan informan dan penggalangan informasi oleh pegawai DJBC bidang Penyidikan dan Penindakan bukannlah hal baru. Bahkan, itu sudah menjadi salah satu tugas pokok. Meski dibutuhkan dana untuk membina para informan, anggaran yang dibutuhkan tetap jauh lebih kecil dan lebih mudah dipenuhi dibandingkan bila harus menambah kapal baru beserta awaknya. Kombinasi informasi terverifikasi dari informan dan penggerahan kapal secara terfokus adalah salah satu siasat untuk tetap bisa menegah penyelundupan di tengah keterbatasan seperti sekarang. 


\section{Daftar Pustaka}

Arsuka, Nirman Ahmad. "Bumi Langit Karaeng Pattingaloang" dalam JB Kristanto (Ed). 2000. Seribu Tahun Nusantara. Jakarta, Penerbit Buku Kompas.

Bhattacharyay, Biswa Nath. 2010. "Infrastructure for ASEAN Connectivity and Integration". ASEAN Economic Bulletin Vol. 27, No. 2 (2010), pp. 200-220

Dirhamsyah. 2005. Maritime Law Enforcement and Compliance in Indonesia: Problems and Recommendations. Maritime Studies.

Erman, Erwiza. 2009. Menguak sejarah timah Bangka-Belitung:dari pembentukan kampung ke perkara gelap. Penerbit Ombak

Anonim. "Exchange with smuggler who's family name is Siregar". Batam, November $12^{\text {th }} 2014$.

Ford, Michele, and Lenore Lyons. 2013. "Outsourcing Border Security: NGO Involvement in the Monitoring, Processing and Assistance of Indonesian Nationals Returning Illegally by Sea", Contemporary Southeast Asia Vol. 35 (2), pp. 215-34

Frecon, Eric. 2008. The Resurgence of Sea Piracy in Southeast A sia. Irasec.

Harian Pos Metro. 2013. "Gula dan Minuman Selundupan Yang Diangkut Dua Pompong Disergap Polisi” diakses melalui http://posmetrobatam.com/2013/07/gula-dan-minumanselundupan-yang-diangkut-dua-pompong-disergap-polisi/ 21/07/2013

Imigrasi. 2014. Diambil melalui http://www.imigrasi.go.id/index.php/berita/berita-utama/160imigrasi-kini-ada-di-pesawat-garuda-shanghai-jakarta. November $10^{\text {th }} 2014$

Ikawati, Yuni. 2008. “Jumlah Pulau Berkurang”. Harian Kompas. 19 June 2008.

Jamwal, N.S. 2002. "Management of land borders". Strategic Analysis. 26 (3). pp 406-426

Mada, Kris. 2014. "Kepri Pintu Masuk Sabu”. Harian Kompas. 29 April 2014

Mada, Kris. 2014. "Rokok Batam Diselundupkan ke Riau”. Harian Kompas. 28 Agustus 2014

Mada, Kris., 2014, Sindikat Penjual Kulit Ular dari Sumatera Diburu, Harian Kompas 11 June 2014

Ministry Of Marine Affairs And Fisheries. 2011. "Data Pokok Kelautan dan Perikanan 2010".

Naim, Yuniati. 2014. "Bea Cukai Batam Kurang Personel Hadapi MEA 2015”. Kantor Berita Antara http://www.antarasumbar.com/berita/nusantara/d/22/353262/bea-cukai-batamkekurangan-personel-awasi-mea.html, 16/06/2014 08:20 WIB

Nurul. 2013. "10.000 Nelayan Batam Rasakan Dampak Kelangkaan Solar". www.kepribangkit.com, http://www.kepribangkit.com/10-000-nelayan-batam-rasakandampak-kelangkaan-solar.kb 27/02/2014 19:11 WIB

Off-the-record exchange with DJBC officer in Batam, November $5^{\text {th }} 2014$

Pencawan, Yoseph. 2014. "Bea dan Cukai Batam Buka Lowongan Personel Patroli". Bisnis Indonesia http://batam.bisnis.com/m/read/20140812/10/45164/bea-dan-cukai-batam-buka -lowongan-personel-patroli 12/08/2014/ 18:24 WIB

Ramcharan, Robin. "The Indonesia Revolution And The SIngapore Connection, 1945-1949". Pacific Affairs, 2006. p 156

Santosa, Iwan. 2014. Tionghoa dalam sejarah kemiliteran:sejak Nusantara sampai Indonesia. Jakarta: Penerbit Buku Kompas.

Santosa, Iwan., 2014. “Awak KRI John Lie Ke Inggris”. Harian Kompas 31 May 2014

Sciascia, Alban. 2013. "Monitoring the Border: Indonesian Port Security and the Role of Private Actors". Contemporary Southeast Asia Vol. 35, (2), pp. 163-187

Sofyan, Ahmadi., 2011. Amung Tjandra: Inspirator. Aynat Publishing.

Storey, Ian. 2009. "Maritime Security In Southeast Asia: Two Cheers for Regional Cooperation". Southeast Asian Affairs. pp 36-58

Tagliacozzo, Eric. "Border Permeability and The State in Southeast Asia : Contraband and Regional Security". Contemporary Southeast Asia. 23 (2) 2001, pp 254-274

Tagliacozzo, Eric. "Smuggling in Southeast Asia: History and its Contemporary Vectors in an Unbounded Region", Critical asian studies. 34 (2) 2002. pp 193-220 